\title{
IDENTIFIKASI MATERIAL DENGAN TOMOGRAFI MUON KOSMIK MENGGUNAKAN DETEKTOR BERBASIS CMOS MEMANFAATKAN WEBCAM
}

\author{
MUHAMMAD RIZKY NURAWAN*, DHIO ALFAFIAN, AKHMAD SAUFI, RAFIF TRI ADI \\ BAIHAQI, CUKUP MULYANA, NOWO RIVELI \\ Prodi Fisika, \\ Fakultas Matematika dan Ilmu Pengetahuan Alam, Universitas Padjadjaran \\ Jl. Raya Bandung-Sumedang Km 21, Jatinangor 45363 \\ *email : muh.rizkynurawan@gmail.com
}

\begin{abstract}
Abstrak. Partikel muon $(\mu)$ adalah partikel elementer yang dihasilkan oleh sinar kosmik ketika menembus ke permukaan bumi dan dapat kita temui dalam kehidupan sehari-hari. Muon memiliki muatan negatif seperti halnya elektron dengan massa 207 kali dari massa elektron atau $105,7 \mathrm{MeV} / \mathrm{c}^{2}$. Waktu hidup muon sekitar $1.5 \mu$ s (proper time) bergerak dengan kecepatan 0.994c. Sekitar 10.000 muon mencapai setiap meter persegi permukaan bumi setiap menit. Keberadaan muon dapat dimanfaatkan dalam kehidupan, untuk mendiagnosa lokasi keberadaan sebuah objek ditempat yang tersembunyi. Prinsipnya sama seperti halnya sinar X, dengan prinsip mengolah citra dapat dimanfaatkan untuk diagnosa kondisi tulang, gigi serta organ tubuh yang lain. Permasalahannya untuk memanfaatkan muon di berbagai macam sektor kehidupan adalah alat detektornya memerlukan teknologi yang canggih, biaya yang besar. Untuk mengatasi permasalahan ini, kami memiliki gagasan untuk membuat alat pendeteksi muon dengan prinsip dan teknologi yang relatif sederhana sehingga dengan mudah dapat dilakukan oleh siapapun. Prinsip kerjanya Muon ditangkap oleh sensor CMOS, interaksi antara sensor CMOS dengan muon mengeksitasi energi elektron yang menghasilkan arus listrik kemudian di konversi ke tegangan, dengan menggunakan perangkat lunak Python hasil tangkapan citra muon oleh CMOS diolah sehingga memberikan informasi tentang intensitas, dan frekuensi (jumlah muon yang menumbuk per satuan luas/per satuan waktutertentu).
\end{abstract}

Kata kunci :muon, detektor, sensor CMOS, sinar kosmik

Abstract. Particles, muons $(\mu)$ is the elementary particles produced by cosmic rays when it penetrates into the surface of the Earth and can we meet in everyday life. Muons have a negative charge of the electron as it does with a mass of 207 times the mass of the electron or $105.7 \mathrm{MeV} / \mathrm{c}^{2}$. Muon life time approx. $1.5 \mu$ s (proper time) moving with speed of $0.994 \mathrm{c}$. About 10,000 muons reaching every square meter of the surface of the Earth every minute. The existence of a muon can be utilized in life, to diagnose the existence of a location of an object in a hidden. The principle is the same as with X-rays, with a principle of image processing can be used to diagnose the condition of the bones, teeth and other body organs. The problem to muons in utilizing a wide range of sectors of life detector is a device that requires sophisticated technology, the costs are great. To resolve this issue, we have the idea of muon detector tool to make the principle of a relatively simple technology and so can easily be done by anyone. The principle of work of the Muon is captured by the CMOS sensor, the interaction between the CMOS sensor with excite electrons energy muon that produces electric current is then converted to a voltage, using the Python software catches muon image by CMOS is treated so that it give information about intensity, and frequency (the number of muon are mashing per unit area/per unit oftime.

Keywords :muon, detector, sensor CMOS, cosmic ray 


\section{Pendahuluan}

Dalam kehidupan sehari-hari tanpa kita sadari bahwa manusia berinteraksi dengan banyak senyawa bahkan partikel yang sering beredar disekitar kita seperti gelombang elektromagnetik, partikel dari peluruhan radioaktif. Salah satu diantaranya adalah partikel yang dibentuk ketika sinar kosmik berinteraksi dengan udara disekitar atmosfer. Muon $(\mu)$ adalah salah satu partikel elementer yangterbentuk ketika sinar kosmik bertumbukan dengan atom-atom yang berada di atmosfer berjarak ribuan kilometer diatas permukaan Bumi. Muon memiliki muatan negatif seperti halnya elektron dengan massa 207 kali dari massa elektron atau $105,7 \mathrm{MeV} / \mathrm{c}^{2}$ (A.Sewell,2007). Partikel elementer yang ada disekitar kita setiap waktu adalahpartikel muon yang berasal dari sinar kosmik. Sinar kosmik adalah partikel elementer yang datang dari luar bumi. Asal usul dari sinar kosmik ini masih menjadi objek penelitian sampai saat ini. Salah satu kandidat teori asal usul sinar kosmik adalah dari ledakan bintang (supernova) dan biasa disebut Galactic Cosmic Rays (Carslaw,2002). Dari sekian banyak partikel elementer yang terbentuk saat sinar kosmik berinteraksi dengan atmosfer, sebagian besar adalah partikel Muon. Namun, keberadaannya tidak dapat kita ketahui padahal kita seharusnya merasakan kehadiran muon tersebut. Keberadaan muon disekitar kita dapat dimanfaatkan (Hidayat, Dody. 2004). Manfaat muon dalam kehidupan sehari-hari untuk mendiagnosa lokasi keberadaan sebuah objek ditempat yang tersembunyi.

Saat ini permasalahannya, alat pendeteksi muon memerlukan fasilitas yang canggih dan kompleks yang bertempat di Massachusetts Institute of Technology USA, serta Los Alomos National University USA dengan biaya pembuatan dan operasi yang besar. Gagasan kreatif kami dalam program karsa cipta ini adalah membuat alat pendeteksi muon dengan menggunakan sensor CMOS (Complementary Metal Oxide Semiconductor) yang sudah tersusun di dalam webcam dilengkapi dengan software pengolah citra python. Saat ini ada teknologi yang tersedia dengan mudah diperoleh dan bisa dimanfaatkan sebagai deteksi partikel, yaitu Sensor CMOS yang terdapat pada kamera digital (E CruzZaragoza,2015). Baru-baru ini, sensor piksel aktif CMOS telah diuji bahkan digunakan untuk mendeteksi keberadaan partikel. Detektor berbasis sensor CMOS tersebut akan memiliki kemampuan untuk mendeteksi partikel elementer termasuk radiasi elektromagnetik sama seperti halnya gamma, sinar $\mathrm{X}$, serta partikel lain seperti muon, alfa, danbeta.

Detektor partikel elementer adalah alat yang digunakan untuk mendeteksi, melacak, atau mengidentifikasi keberadaan partikel berenergi tinggi dengan yang berasal dari sinar kosmik. Seperti radiasi yang dihasilkan dari peluruhan zat radioaktif, partikel sinar kosmik ini memiliki banyak manfaat, tetapi karena keberadaannya belum bisa di deteksi dengan baik, partikel tersebut belum dapat dimanfaatkan. Berbeda dengan sejumlah partikel yang selama ini banyak digunakan di berbagai bidang aktivitas penelitian atau di industri, sumber radiasinya harus terlebih dahulu dibuat. Sedangkan partikel dari sinar cosmic ini dapat ditemukan di setiap tempat maka jika partikel ini bisa dideteksi dengan mudah bisa digunakan untuk berbagai kepentingan (Melissinos, A.C. 2003).

Detektor untuk mendeteksi partikel yang berasal dari sinar kosmik saat ini belum banyak tersedia di Indonesia. Detektor partikel elementer mempunyai peran penting terutama di bidang sains dan pendidikan, selain itu juga banyak 
terapannya di berbagai bidang. Oleh karena itu, tujuan dari makalah ini membuat alat detektor berbasis sensor CMOS yang mampu untuk mendeteksi partikel muon yang berasal dari sinar kosmik. Sensor CMOS yang digunakan berasal dari webcam. Alat detektor partikel muon ini sebelumnya belum pernah ada di Indonesia. Dengan memanfaatkan partikel muon, alat detektor ini diharapkan mampu mengidentifikasi suatu material tertentu yang dapat diaplikasikan pada security suatu perusahaan untuk radiografi (skala besar) sebuah mobil kontainer ataupun di bandara yang mendeteksi material di dalamnya seperti zat yang mengandung bahan berbahaya, di bidang geothermal untuk mendeteksi tingkat pengendapan silica scaling di pipa geotermal, serta untuk memonitor aktivitas gunungberapi.

\section{Metode Penelitian}

Muon terbentuk ketika sinar kosmik berinteraksi dengan udara di atmosfer seperti pada gambar 1.

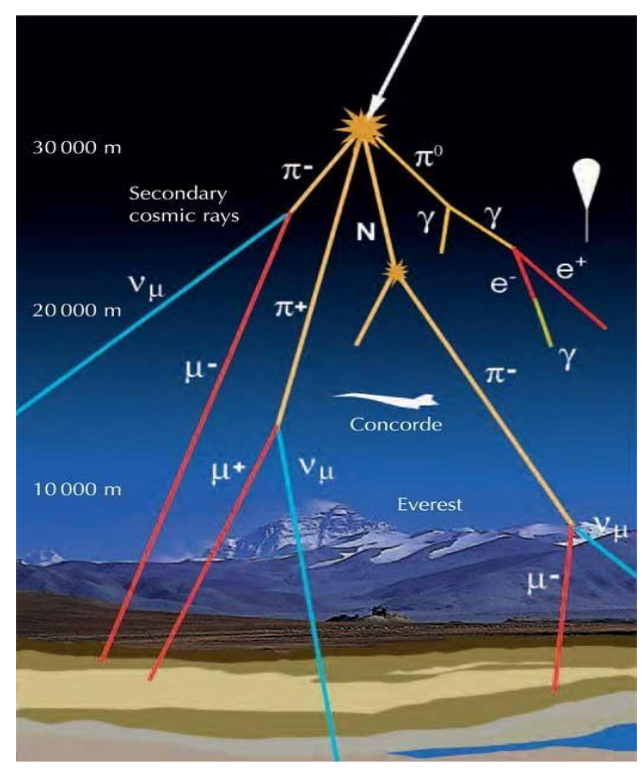

Gambar 1. Skema Muon terbentuk ketika sinar kosmik berinteraksi dengan atmosfer

Muon yang terbentuk meluruh waktu hidup muon sekitar $1.5 \mu$ s (proper time) bergerak dengan kecepatan 0.994c. Sekitar 10.000 muon mencapai setiap meter persegi permukaan bumi setiap menit. Kemudian muon tersebar di sekeliling kita, dan ditangkap oleh alat detektor muon. Blok diagram dari alat detektor muon terdiri dari 4 bagian utama, yakni box detektor, USB Hub, perangkat lunak Python, danLaptop. 


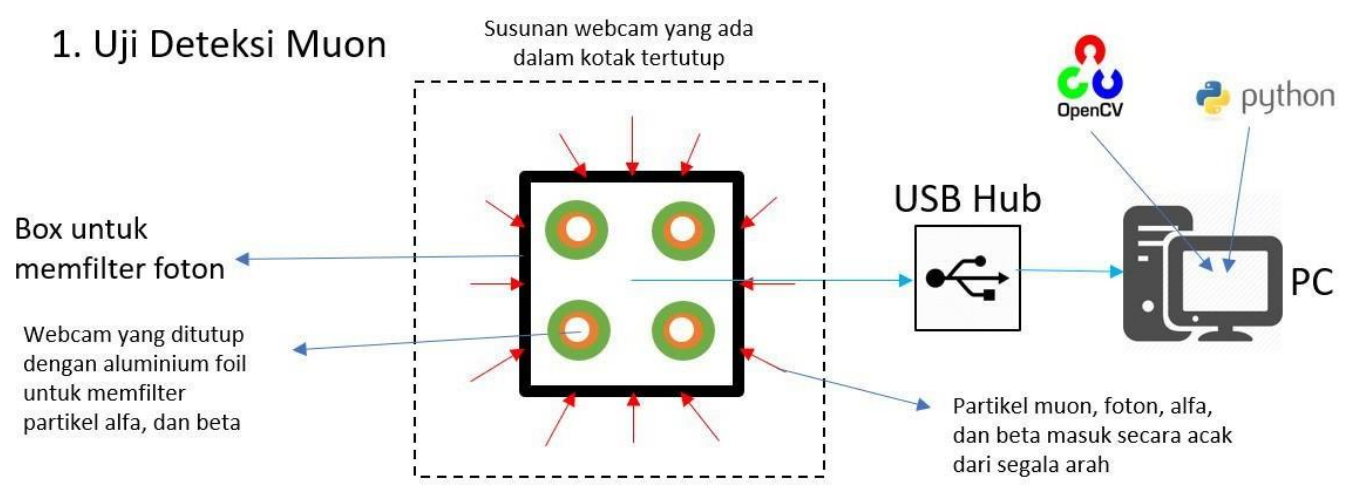

Gambar 2. Design Prototype Detektor Partikel Muon

Di dalam box detektor berisi filter foton, filter peluruhan zat radioaktif, dan webcam yang berisi sensor CMOS. Webcam yang digunakan berjumlah 8 buah. Berbagai macam sinar kosmik, gelombang elektomagnetik, peluruhan zat radioaktif masuk kedalam box detektor. Gelombang elektromagnetik di filter oleh box detektor yang kedap cahaya tampak sehingga gelombang elektromagnetik tidak bisa masuk kedalam box. Berikutnya partikel peluruhan zat radioaktif yang berada didalam box terfilter oleh lapisan alumunium foil, dan sisa partikel yang masuk kedalam webcam (Sensor CMOS) adalah partikel muon. Sensor CMOS yang berada didalam webcam mendeteksi keberadaan muon karena muon berinteraksi dioda yang berada didalam sensor CMOS. Elektron bebas yang terbentuk pada dioda, dihasilkan arus yang dialirkan dengan USB Hub. Kemudian diolah oleh perangkat lunak Python menghasilkan citra muon berupa foto keberadaan muon yang terukur dari intensitasnya kemudian di tampilkan pada laptop. Diagram dari penggunaan muon untuk deteksi benda asing dilihat pada gambar 3. Prinsip kerjanya sama seperti blok diagram pada gambar 2 tetapi ditambahkan material yang akan di deteksi dalamnya dan ditambahkan sensor CMOSkedua.

2. Uji Identifikasi Material

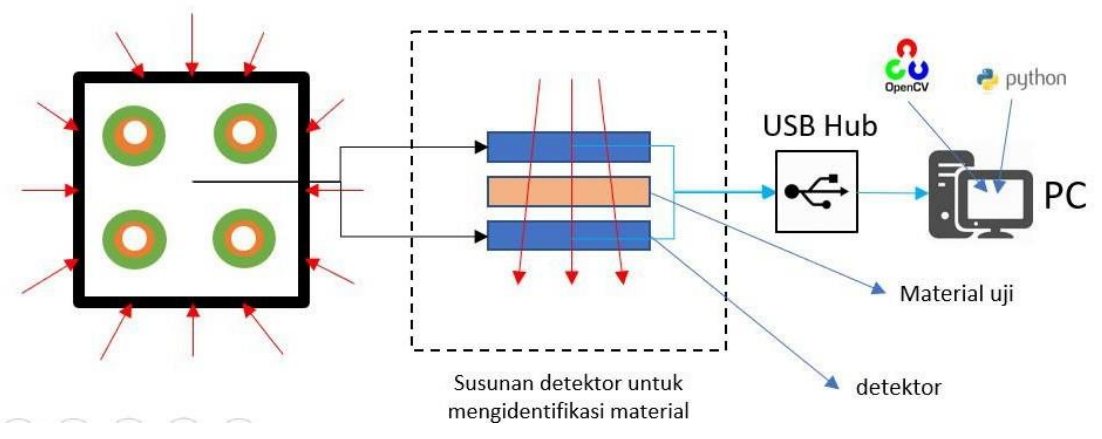

Gambar 3. Design Prototype Partikel untuk mendeteksi material

Muon yang sudah dideteksi pada CMOS kedua melewati material X yang akan dideteksi. Sejumlah muon diserap/dipantulkan sehingga intensitas muon berkurang dan ditangkap oleh sensor CMOS kedua. Selanjutnya CMOS dihubungkan dengan USB Hub, dan seperti pada prinsip kerja diagram blok 
gambar 2 citra muon diperoleh dan gambar muon dapat ditampilkan pada laptop. Hasil perbedaan dari alat detektor muon dan alat detektor material dengan menggunakan muon ditampilkan pada gambar 3.

Langkah berikutnya adalah merangkai komponen-komponen yang diperlukan untuk membuat alat deteksi muon. Komponen-komponen tersebut terdiri dari Webcam Logitech C270, Kabel USB, USB Hub, Lem, Alumunium Foil, perangkat lunak Python, dan Laptop . Berdasarkan dari rancangan desain alat pada gambar 2 dan 3 maka diperoleh rangkaian alat detektor seperti pada gambar 4 .

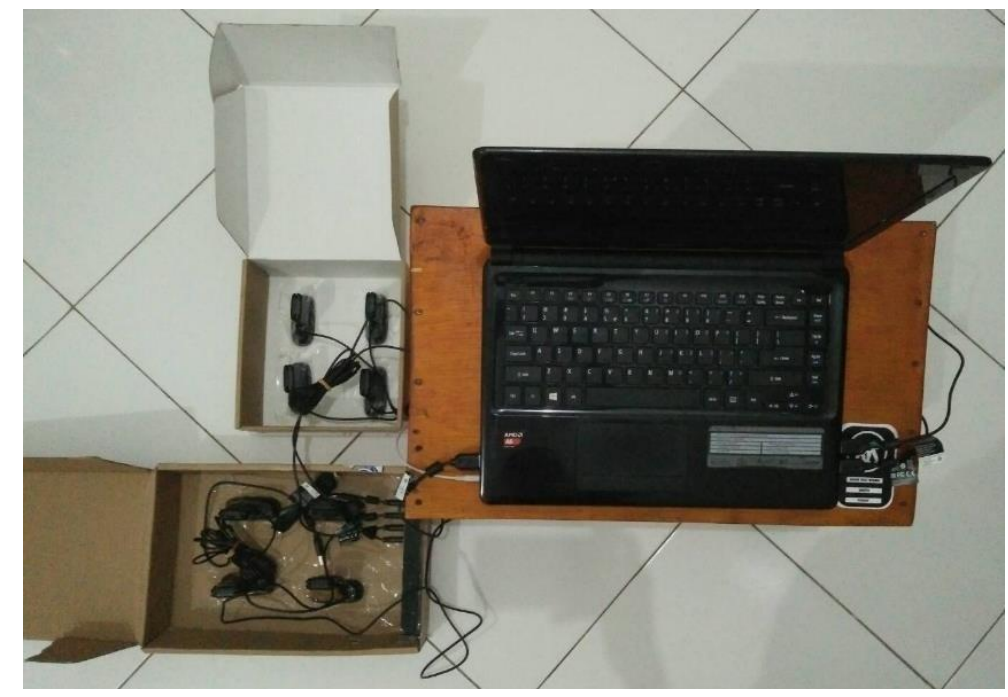

Gambar 4. Rangkaian alat detektor partikel muon

Webcam Logitech C270 digunakan sebanyak 8 buah yang ditempatkan dalam box tertutup (kedap cahaya tampak), dihubungkan oleh kabel USB ke USB Hub, lalu dari USB Hub dihubungkan ke Laptop. Didalam Laptop telah terinstall perangkat lunak Python.

\section{Hasil dan Pembahasan}

\subsection{Alat DetektorMuon}

Dari hasil yang dicapai kita dapat membuat alat detektor untuk mendeteksi keberadaan muon. Ketika detektor ini disambungkan dengan Laptop yang dijalankan oleh program Opencv, maka detektor ini akan menangkap keberadaan muon yang beredar disekitar kita. Untuk memastikan muon yang dapat dideteksi, maka dilakukan filter untuk membloking gelombang elektromagnetik, maupun sinar alfa yang masuk ke sensor CMOS. Dengan kondisi box ini ditutup rapat tidak ada cahaya yang masuk, lalu di sensor CMOS diberi alumunium foil memfilter sinar alfa yang masuk maka akan mendapatkan citra / sinyal yang tampil di Laptop berupa titik-titik putih kecil dan ini merupakan keberadaan muon yang tertangkap oleh detektor, sedangkan beda kondisi ketika box ini dalam keadaan disinari oleh cahaya maka citra/sinyal yang dihasilkan ini terinterverensi 
oleh keberadaangelombang elektromagnetik disekitarnya yang menyebabkan hasilnya tampil di laptop berupa titik putih juga tetapi sangat banyak.

1. Kondisi ketika tidak ada partikel muon (background) yang tertangkap didetector

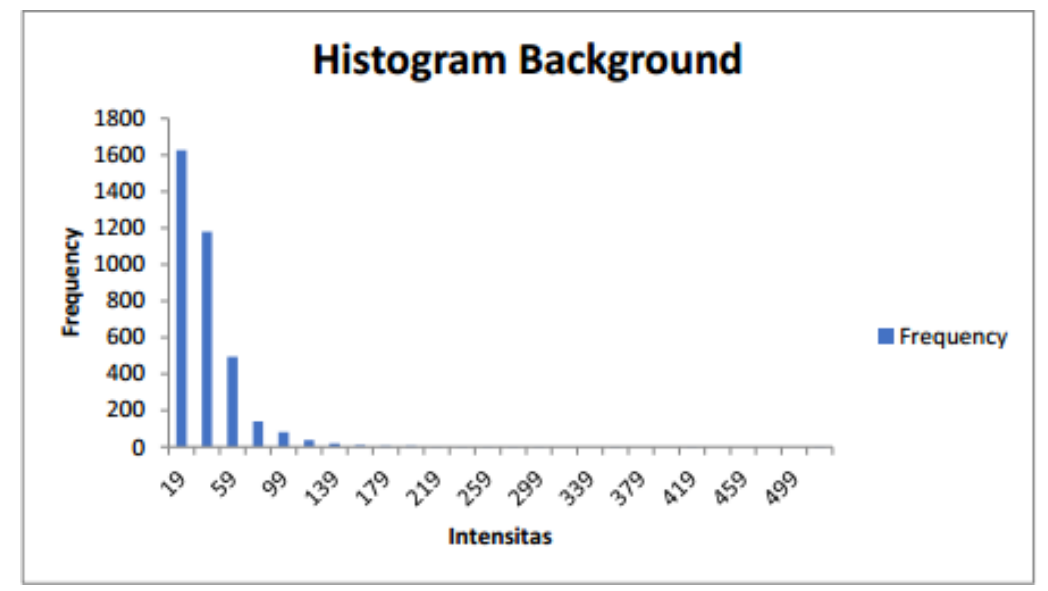

Gambar 5. Histogram ketika tidak ada partikel

Histogram pada gambar tersebut terdapat data sebanyak 3607 gambar yang tertangkap oleh webcam. Gambar ini menunjukkan bahwa intensitas paling banyak terdapat pada rentang 0-19. Ini dikarenakan alat detektor partikel yang dibuat dalam kondisi sangat gelap sehingga tidak ada cahaya tampak yang masuk.

2. Kondisi ketika ada partikel muon/sinyal yang tertangkap didetektor

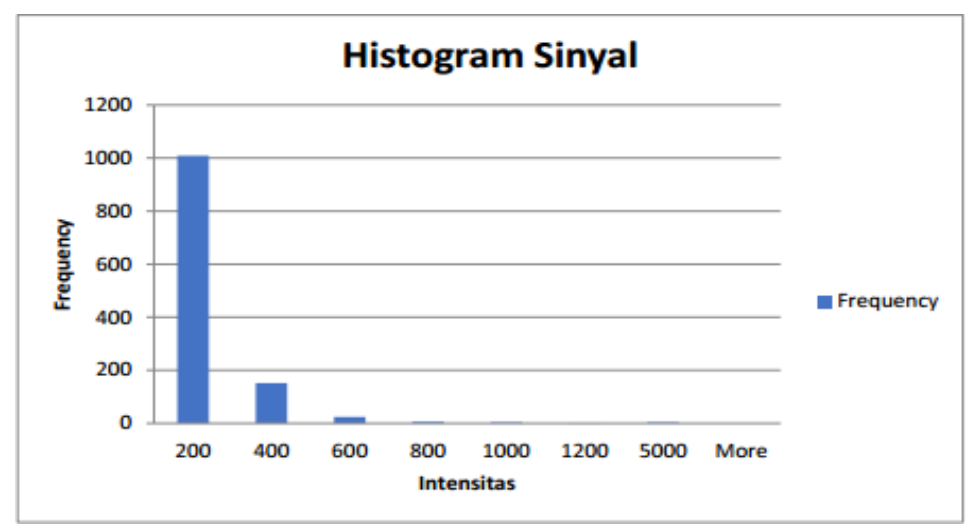

Gambar 6. Histogram ketika ada sinyal yang tertangkap

Ketika ada partikel yang melewati detektor dinamakan sinyal. Setelah pengambilan data mendapatkan data sinyal sebanyak 1200 gambar yang disajikan dalam bentuk histogram pada gambar 6 . Dapat dilihat histogram pada Gambar 6, intensitas sinyal paling banyak terdapat pada rentang 0-200 atau lebih tepatnya intensitas 100 sampai 200 sebanyak 1009 gambar. Dari 1200 gambar yang 
terdapat sinyal tersebut selanjutnya di cari intensitas yang maksimum dari setiap gambar tersebut. Dapat dilihat dari histogram pada Gambar 5, menunjukkan bahwa intensitas total background paling banyak beradapada rentang 0 sampai 99 . Maka dari histogram tersebut akan ditentukan nilai thresholding, ketika ada partikel yang melewati detektor. Thresholding merupakan salahsatumetodesegmentasicitrayangmemisahkanantaraobjekdenganbackground dalam suatu citra berdasarkan pada perbedaan tingkat kecerahannya atau gelap terangnya (Adi Pamungkas, 2017). Dilihat dari intensitas total background tersebut, maka untuk threshold intensitas total yang ditentukan jika intensitas lebih besar dari 100 menandakan ada partikel yang melewati detektor.

Pengamatan terhadap keberadaan muon dilakukan dengan cara:

1. Mengambil 1500 citra webcam yang tidak teridentifikasi adanya muon (dilihat dari citra webcam berwarnahitam).

2. Mengambil 1500 citra webcam yang teridentifikasi adanya muon (dilihat dari citra webcam yang berwarnaputih).

Setelah diolah dengan perangkat lunak python intensitas dari kondisi ketidak adaan muon nilai intensitasnya rendah dengan frekuensi yang rendah pula seperti yang terlihat pada gambar 3 (histogram berwarna kuning). Sedangkan kondisi ketika muon teridentifikasi pada keadaan yang ditunjukan oleh intensitas yang tersebar sampai nilai 35 dengan frekuensi yang lebih tinggi dibandingkan dengan kondisi tanpa muon (histogram berwarna biru). Keberadaan muon akan meningkatkan frekuensi yang ditangkap olehwebcam.

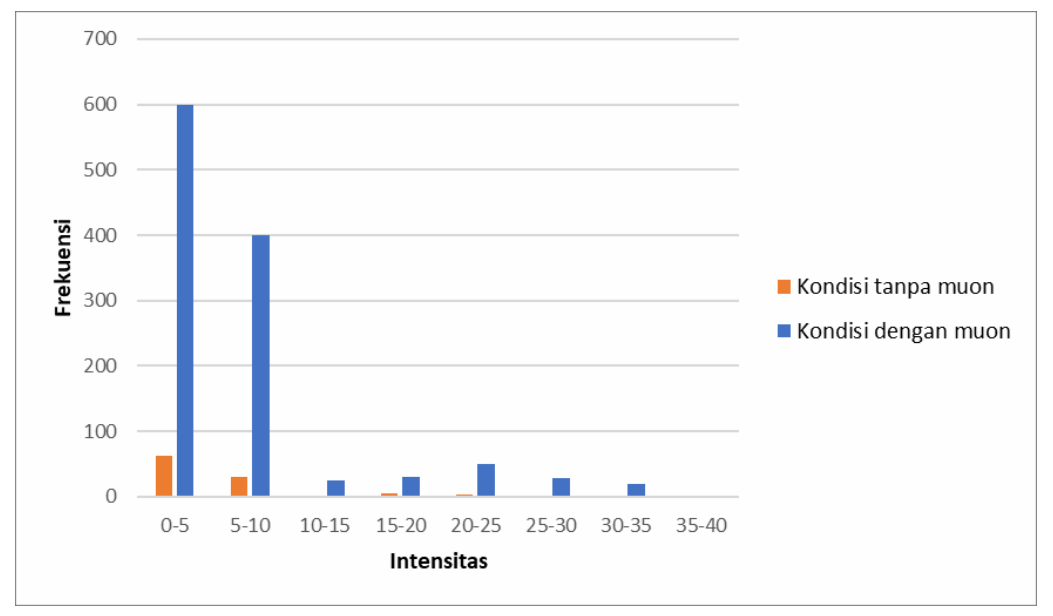

Gambar 7. Histogram perbandingan ketika ada muon dan tanpa muon pada intensitas maksimum

Dari hasil pengamatan yang dilakukan 1200 kali tidak teramati adanyamuon seperti ditunjukan pada gambar 8, intensitas yang terdeteksi sebagian besar dibawah nilai 10 dan sebagian kecil pada interval 10 hingga 25. Ketika terdeteksi adanya muon dari dari 1200 citra webcam yang setelah diamati sebagian besar nilai intensitasnya dibawah 10 , sedangkan nilai intensitas tanpa adanya muon nya diatas 25. Dapat dilihat histogram pada Gambar 8, menunjukkan bahwa nilai intensitas yang maksimum dari 1200 gambar masih banyak intensitas yang rendah di rentang 0-24. Dengan diselidiki untuk nilai intensitas yang maksimum dari gambar yang terdapat sinyal tersebut, berarti untuk menentukan adanya sinyal dengan menggunakan intensitas total masih banyak intensitas yang maksimum yangrendah. 
Dapat dilihat keberadaan muon pada tingkat intensitas yang maksimum berupa titik putih seperti terlihat pada Gambar 9. Tingkat intensitas pada gambar tersebut diperoleh untuk bacground dengan rentang 0-25. Batas threshold untuk intensitas pada background adalah 25. Jika intensitas yang diperoleh lebih besar dari 25 berarti menandakan ada partikel yang melewati detektor. Dalam percobaanini webcam mengambil sebanyak 7.795 gambar selama 243.091,788 detik.

Selanjutnya dilakukan seleksi data yang memiliki intensitas yang maksimum lebih besar dari 20. Dari hasil seleksi diperoleh 684 gambar yang memiliki intensitas yang lebih besar dari 20. Selanjutnya Ke 684 gambar tersebut dilakukan pembesaran. Gambar 8 menunjukkan citra muon hasil pembesaran tertangkap oleh webcam. Sedangkan 9 adalah grafik dari intensitas yang maksimum yang bernilai di atas 20 sebagai fungsifrekuensi.

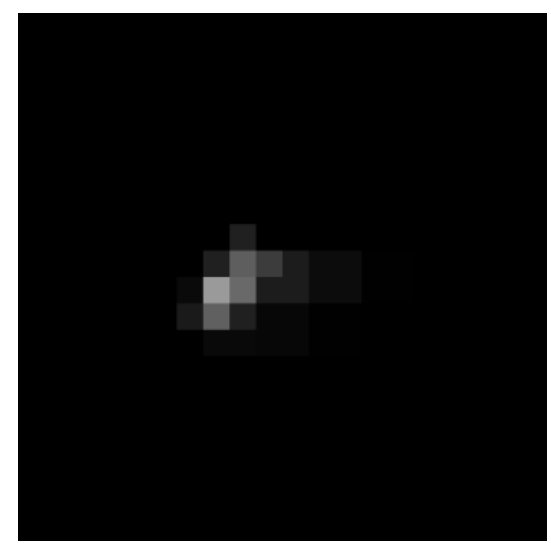

Gambar 8. Citra muon yang tertangkap oleh webcam

\subsection{Alat Detektor Material dengan menggunakan Muon}

Telah dilakukan percobaan untuk menguji keberadaan benda asing dengan menggunakan alat detektor partikel muon. Partikel yang akan diuji adalah material terbuat baja SA-213 T22 berukuran $(3 \times 1 \times 0,4) \mathrm{cm}$. Objek tersebut diletakan diantara dua webcam seperti terlihat gambar 8 . Citra yang ditangkap oleh webcam dan setelah dikonversi dengan menggunakan perangkat lunak python,dihasilkan grafik frekuensi terhadap intensitas. Hasil deteksi webcam pertama menghasilkan grafik frekuensi terhadap intensitas seperti pada gambar 9. webcam pertama ini memberikan informasi berapa intensitas muon dan frekuensi keberadaan muon sebelum mengenai objek yang akan diuji (materialX). 


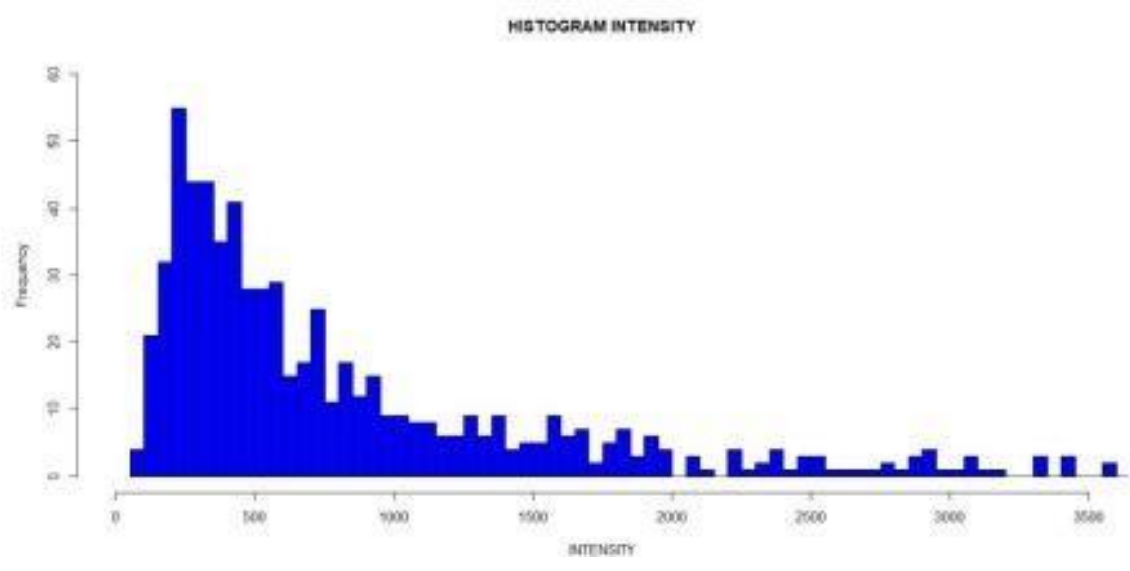

Gambar 9. Histogram intensitas terhadap frekuensi muon sebelum melewati benda uji

Pengambilan data mendapatkan data sebanyak 6.135gambar selama 229.169,319 detik. Menghasilkan 692 gambar yang intensitas yang maksimum lebih besar dari25. Selanjutnya muon melewati material yang akan diuji. Setelah melewati material muon ditangkap oleh sensor CMOS kedua untuk dihitung kembali intensitas dan frekuensinya. Gambar 10 menunjukan histogram intensitasterhadap frekuensi muon setelah melewati benda uji. Ketika detektor ini diberikan material berupa baja SA-213 T22, maka didapatkan citra yang memberikan informasi keberadaan muon yang dinyatakan dalam intensitas terhadap frekuensi seperti ditampilkan pada gambar 10.

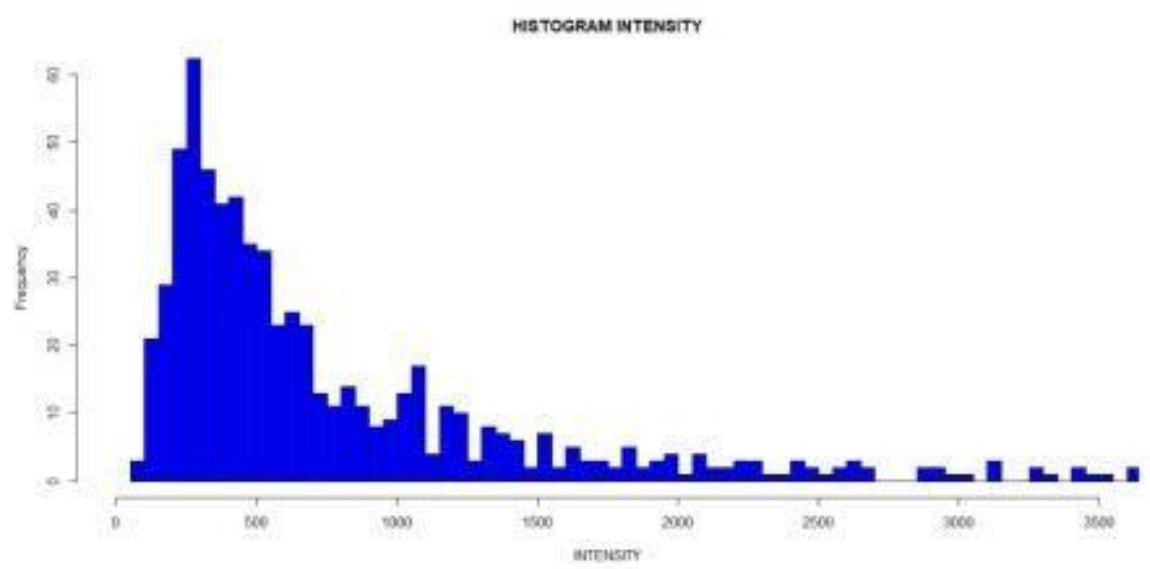

Gambar 10. Histogram dengan intensitas ketika menggunakan SA-213 T22

Pola histogram intensitas terhadap frekuensi untuk pendeteksian muon sebelum melewati benda asing yang akan dideteksi dan yang setelah melewatinya menunjukkan pola yang serupa. Hal ini menjelaksan bahwa muon yang terdeteksi oleh kedua webcam adalah muon yang sama. Ada sedikit perbedaan dalam frekuensi, di sekitar muon dengan intensitas yang sama. Seharusnya jika tidak ada pengaruh luar nilai intensitasnya berharga sama. Secara teoritis untuk frekuensi yang sama intensitas muon sebelum melewati benda asing yang akan dideteksi seharusna lebih tinggi dibandingkan setelah melewati benda asing. Selisih anatara 
antara ke dua intensitas tersebut menyatakan menurunnya energi muon karena sebagian kecil diserap oleh benda asing.

\section{Kesimpulan}

Alat detektor partikel berbasis sensor CMOS yang dibuat dapat mendeteksi partikel sinar kosmik berupa muon. Namun dari webcam yang digunakan memiliki kemampuan yang terbatas untuk mendeteksi partikel sinarkosmik.

Alat uji identifikasi material ini merupakan tahap awal untuk standarisasi membedakan material yang digunakan darikarakteristiknya.

\section{Ucapan terima kasih}

Terimakasih kepada semua pihak yang telah membantu dalam penyelesaian penelitian ini, terutama pada Pak Cukup Mulyana dan Pak Nowo Riveli yang selalu sabar dalam membimbing kami, serta kepada Kementristekdikti yang telah memberikan dukungan berupa materil sehingga kami dapat menyelesaikan penelitian ini.

\section{Daftar Pustaka}

1. A. Elouardi, S. Bouaziz, A. Dupret, L. Lacassagne, J. O. Klein, R. Reynaud, CMOS Image Sensor Versus Retina Experience. IEEE Sensor, Wina, Austria, 2004.

2. A. Sewell. The Speed and Mean-Life of Cosmic-Ray Muons.8.13 CourseReader, 2007.

3. Ade. 2009. Image Processing. Diambil dari: http://ndoware.com/imageprocessing.html (Akses: 27 Oktober 2017)

4. K. S. Carslaw, R. G. Harrison, J. Kirkby, Cosmic rays, clouds, and climate, Science, 298 (2002) p.1732-1737.

5. D. Litwiller, CDD vs. CMOS: Fact and Fiction, DalsaCorp, 2001.

6. A. Halim, Fisika Modern I (Pendekatan Konseptual). Banda Aceh: Syiah Kuala UniversityPress, 2013.

7. E. Cruz-Zaragoza, I. P. López, CMOS sensor as charged particles and ionizing radiation detector. Journal of Physics: Conference Series 582 (2015) 012047.

8. E. R. Fossum, CMOS Image Sensors: Electronics Camera-on-A-Chip. IEEE Transactions on Electron Devices (1997) p. 1689 -1698.

9. D. Hidayat, 2004. Terungkapnya Asal-usul Sinar Kosmis. www.fisikanet.lipi.go.id. Diakses pada 27 Agustus2017.

10. Image Sensor Architectures for Digital Cinematography, Dalsa Corp. Imaging and Multimedia Technology II, 85580O; doi:10.1117/12.2000538

11. J. Dubois, D. Ginhac, M. Paindavoine, B. Heyrman, A 10000 fps CMOS Sensor With Massively Parallel Image Processing, Journal of Solid-State Circuits, IEEE (2008) p.706-717.

12. A. C. Melissinos, Experiments in Modern Physics, "De-tection of Cosmic Rays". 2nd Edition: AcademicPress (2003). 